\title{
Uma digitação do Prelúdio da Suíte para Alaúde BWV 997 de J. S. Bach transcrito para o violão
}

\section{Fingerings for J. S. Bach's Prelude from the BWV 997 Lute Suite transcribed for the guitar}

\author{
Natanael Martins de Sousa ${ }^{1}$ \\ Marcos da Silva Maia ${ }^{2}$ \\ ${ }^{1}$ Universidade Estadual do Ceará, Fortaleza, Ceará, Brasil \\ nael_thelifemusic@yahoo.com.br \\ ²Universidade Estadual do Ceará, Fortaleza, Ceará, Brasil \\ marcosmaiamusic@gmail.com
}

Resumo: Este trabalho apresenta uma digitação violonística para transcrições do prelúdio da Suíte BWV 997, original para alaúde, de Johann Sebastian Bach (1685-1750). Os aspectos musicais abordados para fundamentar a digitação foram divididos e classificados em motivo, melodia polifônica, contraponto, arpejo e homogeneidade tímbrica. O cotejamento foi aplicado como modelo de análise, em algumas transcrições para violão dessa obra, nas quais foram verificadas digitações diversificadas e notações distintas quanto à representação de alguns valores rítmicos e de determinadas alturas.

Palavras-Chave: digitação violonística; preludio de Bach; transcrição para violão.

Abstract: This paper presents a guitar fingering for transcriptions of Bach BWV 997 Lute Suite Prelude. The musical aspects approached to support fingering were divided and classified into motive; polyphonic melody; counterpoint; arpeggio and timbre homogeneity. We applied comparison as analysis model in some guitar transcriptions of this piece; in which diverse and distinct fingering notations were observed, concerning the representations of some rhythmic values and certain pitches. 
Keywords: guitar fingering; Bach prelude; guitar transcription.

Data de recebimento: 10/02/2015

Data de aprovação final: 23/09/2015

\title{
1 - Introdução
}

Digitação é o termo utilizado para indicar a disposição dos dedos e mãos de um músico ao tocar um determinado instrumento.

\begin{abstract}
A digitação é um processo inerente à prática da maioria dos instrumentos musicais [...], [sendo que] nos instrumentos de cordas, digitar envolve a ação de pressionar as cordas com a mão esquerda e está estreitamente ligada à nota, ao timbre e à expressão (ALÍPIO, 2010, p.10).
\end{abstract}

Para SADIE (1994, p.258), "nos instrumentos executados sem arco, tais como, o alaúde e o violão, o ato de tanger as cordas com a mão direita, chama-se dedilhar". O violão oferece a possibilidade de tanger ou dedilhar a(s) mesma(s) nota(s) em mais de uma localização na escala do instrumento, um dos recursos que torna o processo de digitação uma tarefa de múltiplas possibilidades. Além disso, a variedade de materiais, espessuras e tensões entre suas cordas, produzem uma ampla gama de timbres, gerando diferentes resultados musicais na execução da peça por estarem estreitamente ligados às digitações.

De acordo com WOLFF (2001), a escolha da digitação é um dos elementos mais importantes no aprendizado de uma obra, principalmente em um instrumento como o violão. Para tal procedimento, é necessário um profundo conhecimento do mesmo através de estudo, sendo impossível elucidar em poucas linhas as muitas variáveis encontradas no processo. Por essas razões, realizou-se uma nova digitação para o prelúdio da Suíte $B W V^{1} 997$ de Johann

\footnotetext{
${ }_{1}^{1}$ Abreviatura de Bach-Werke-Verzeichnis: índice das obras de Bach preparado por Wolfgang Schmieder em 1950. As obras são numeradas e prefixadas pelas iniciais BWV (HORTA, 1985, p.58).
} 
Sebastian Bach, visando à execução musical e observancia da digitação nas transcrições ${ }^{2}$ de TURECK (1985), KOONCE (2002), THORLAKSSON (2006) e DELCAMP (2009).

A execução de obras não originais para o violão, através do processo da transcrição, é uma constante na prática interpretativa do instrumento. DART (1991) afirma que o violonista tem, ao seu dispor, um repertório que abrange aproximadamente cinco séculos de música, onde parte desse repertório constitui-se de obras originalmente compostas para instrumentos antigos de cordas dedilhadas como a vihuela e o alaúde. Este último, por exemplo, era um instrumento que podia variar de 6 a 14 ordens (pares de cordas), sendo sua afinação diferente quando comparada ao violão moderno. $\mathrm{O}$ alaúde barroco tinha as seis primeiras cordas afinadas em Lá, Ré, Fá, Lá, Ré e Fá, possuindo de quatro a oito cordas graves adicionais, enquanto o violão tem suas cordas afinadas em Mi, Lá, Ré, Sol, Si e Mi. Pelas diferenças existentes entre as afinações do alaúde barroco e do atual violão são necessárias algumas adaptações para se realizar uma transcrição, adaptações estas que podem apresentar diferenças a serem verificadas. Uma das alterações realizadas pelos quatro transcritores selecionados, com relação à obra original (em Dó menor), foi quanto à mudança de tom: Lá menor. Outro ponto a ser observado é a presença de diferenças também existentes nessas transcrições como, por exemplo, digitações diversificadas e notações distintas quanto à representação de alguns valores rítmicos e de determinadas alturas.

\section{2 - Digitação}

\section{1 - Aspectos Gerais}

Segundo SILVEIRA FILHO (2004, p.12), “A digitação grafada [...], não é necessariamente um texto musical, mas, sim, a indicação de dedos e cordas sobre notas musicais em uma partitura”. Esta possui um sistema de notação própria, que prevê símbolos específicos ${ }^{3}$ para

\footnotetext{
2 6. Mús. Adaptação de uma obra musical a um instrumento ou grupo de instrumentos diferentes dos da versão primitiva. (FERREIRA, 1988, p.644).

${ }^{3}$ Letras e números não circulados escritos acima, abaixo ou ao lado das figuras musicais, indicam o dedo de uma determinada mão que deve atuar em cada nota.
} 
representar, na partitura, a digitação das cordas e/ou dedos. Tal sistema de notação encontrase representado, a seguir, nas Figuras 1, 2 e 3:

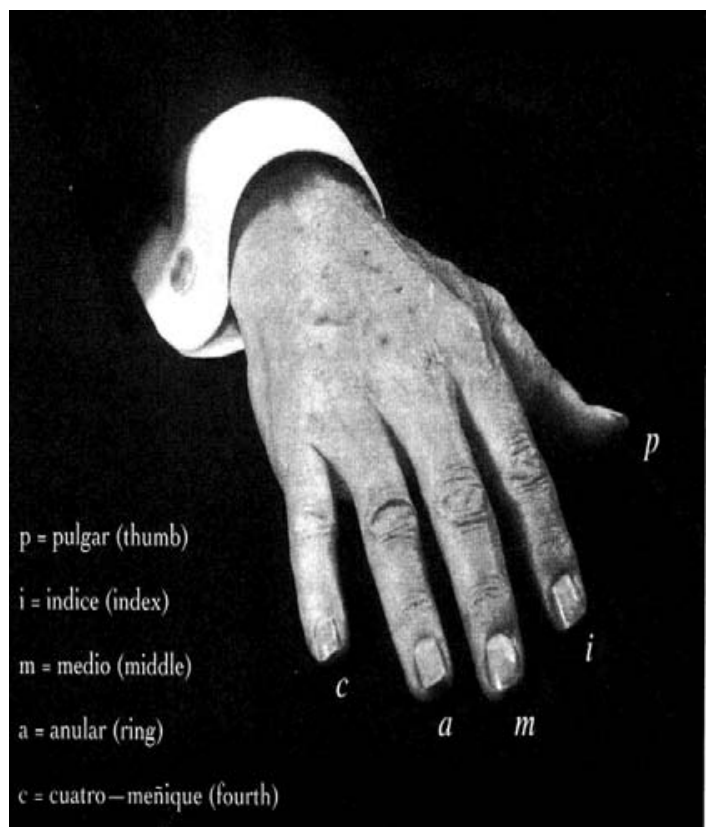

Figura 1: Nomenclatura dos dedos mão direita (POSTLEWATE, 2001, p.56).

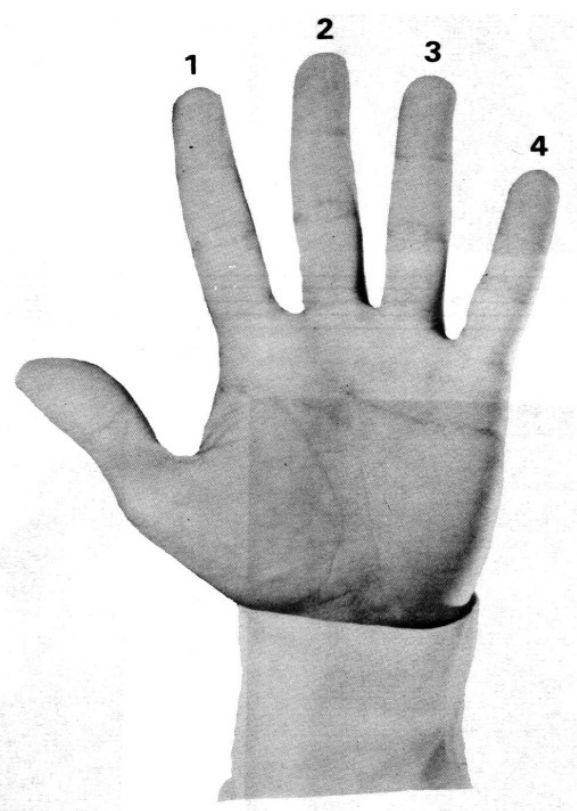

Figura 2: Nomenclatura dos dedos mão esquerda (PINTO, 1978, p.24). 


\section{(0) CORDA SOLTA \\ (1) PRIMEIRA CORDA \\ (2) SEGUNDA CORDA \\ (3) TERCEIRA CORDA \\ (4) QUARTA CORDA \\ (5) QUINTA CORDA \\ (6) SEXTA CORDA}

Figura 3: Representação das cordas soltas do violão (PINTO, 1978, p.16).

Um trecho do prelúdio da Suíte BWV 997, em destaque abaixo na Figura 4, mostra como essa notação é representada na partitura:

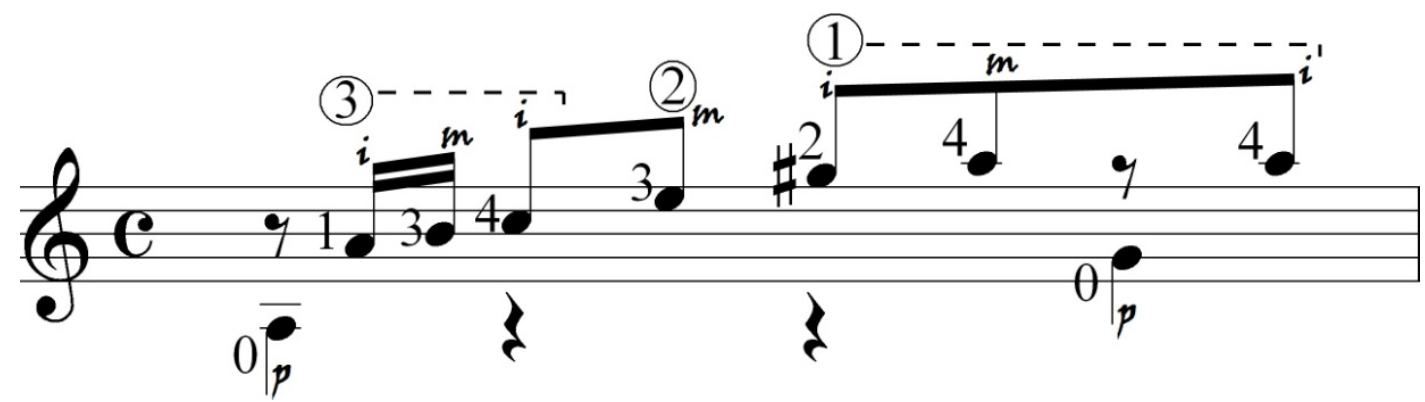

Figura 4: Representação da digitação na partitura.

Os números não circulados representam os dedos da mão esquerda, enquanto os mesmos, circulados, as cordas soltas do violão. O número 0 (zero) circulado ou não, também representa as cordas soltas. Já os dedos da mão direita são representados pelas iniciais de seus nomes: $\mathrm{i}$ - indicador, $\mathrm{m}$ - médio e a - anelar. Em alguns casos, utiliza-se o dedo mínimo, este com a indicação da "letra c [de forma minúscula] - chico, mínimo em espanhol" (MAIA, 2007, p.vi). Quando há necessidade de indicar casas na realização de pestanas usa-se a letra "C" (de forma maiúscula) e o número da casa, ou apenas este último, em algarismo romano. A casa ou pestana, também pode ser indicada pela letra "B" [do francês Barre]. No c.56 da Figura 5 do prelúdio da Suíte BWV 997 estes dois exemplos estão em evidência: 


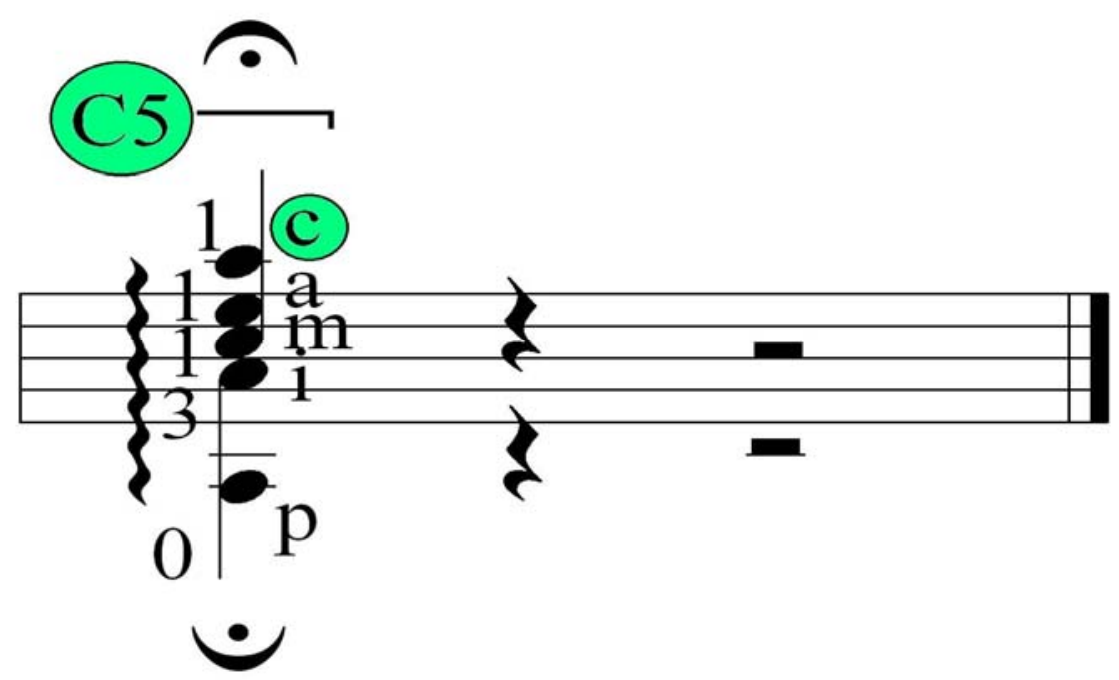

Figura 5: Indicação da pestana e do dedo mínimo da mão direita.

Um dos fatores decisivos na execução de uma obra violonística é a digitação grafada, pois a possibilidade de se tocar uma mesma nota (mesma altura) em pelo menos quatro posições distintas da escala, gera diferentes possibilidades para uma mesma passagem ${ }^{4}$ (ARAÚJO, 2011). O exemplo a seguir, da Figura 6, ilustra duas possibilidades de digitação para o c.1 do prelúdio da Suíte BWV 997:
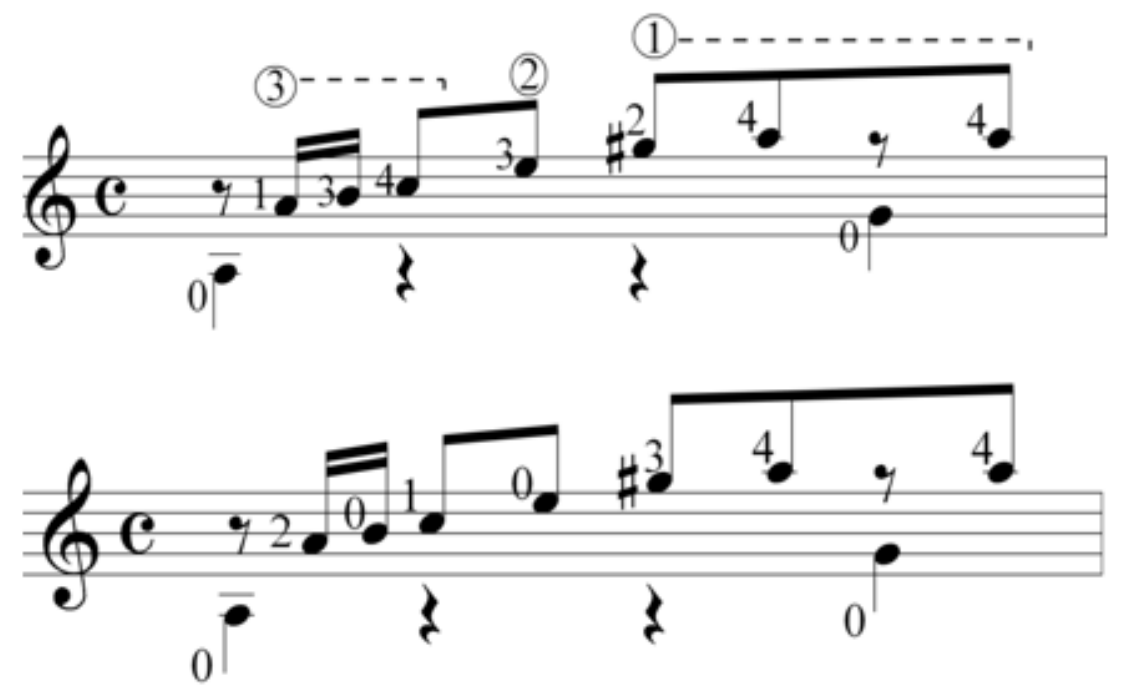

Figura 6: Duas possibilidades para a execução da mesma passagem.

\footnotetext{
${ }^{4}$ Execução com mais legato, articulações distintas para diferentes vozes no caso de uma obra polifônica, variação do timbre, etc.
} 
Nos exemplos dados foram apresentadas duas possibilidades de digitação que, ao executálas, percebe-se a diferença de timbre entre ambas. A melodia da primeira digitação evita as cordas soltas, procurando tocar o máximo de notas possíveis na mesma corda, por sua vez, a segunda digitação usa, em dois momentos, as cordas soltas "Si" e "Mi".

Com essas múltiplas possibilidades o instrumentista encontra-se diante de uma problemática: qual digitação usar? Segundo WOLFF (2001), a escolha da digitação depende de diversos fatores, quais sejam: dificuldade técnica da obra, características individuais (anatomia das mãos, nível técnico e sonoridade do instrumento), estilo da obra e interpretação (fraseado, articulação, timbre, etc.). Entretanto, para essa escolha deverá ser levado em consideração todas as variáveis possíveis, para que esta digitação esteja de acordo com as características da peça musical.

\footnotetext{
É necessário que a busca de uma digitação seja extremamente rigorosa e que tenhamos a paciência de buscar todas as variáveis imagináveis, tendo sempre em conta a relação inseparável entre a digitação e o resultado musical. [...] digitar não é simplesmente buscar a maneira mais fácil de tocar as notas, porém interpretar [...] [Doutra forma] nossas ideias musicais correm o risco de ficar afogadas dentro de um modo de digitação estabelecido quase que ao acaso (FERNANDEZ, 2000, p.15).
}

A digitação deve estar intrinsecamente relacionada com o resultado musical, tornando-se necessário determinado conhecimento da obra, proveniente de observações de práticas interpretativas da época.

O período de composição de uma peça é fator decisivo para uma digitação estilisticamente correta. Nas tablaturas das obras originalmente compostas para os instrumentos precursores do violão, tal como o alaúde e a vihuela, observa-se uma preferência pelas primeiras posições do braço do instrumento, característica esta que deve ser preservada para uma maior autenticidade na execução. Já em obras compostas na segunda metade do século dezenove (Coste, Regondi, Tárrega), favoreciam-se as posições mais agudas e o frequente uso de glissandos. Tais características permaneceram em uso durante boa parte do século vinte, como se pode observar nas digitações de Miguel Llobet e Andrés Segóvia (WOLFF, 2001). 
$\mathrm{O}$ ato de digitar, fator importante para a interpretação musical, não deve ser visto simplesmente como uma prática a serviço da fluidez técnica, pois as características da música estão inerentes às da digitação.

\begin{abstract}
A escolha da digitação de mão esquerda é determinada pelo contexto melódico e harmônico, e o compromisso entre o efeito musical, a sonoridade do instrumento e conveniência técnica. Digitação melódica, que se movem estritamente nota-a-nota, sem permitir qualquer sobreposição de notas dentro da linha, estão em contraste com digitações harmônicas, que permitem a sobreposição de notas pertencentes à mesma harmonia, embora a notação não possa indicar isto. $\mathrm{O}$ fator decisivo na escolha de um sistema sobre o outro é decidido pelo contexto musical e pela sonoridade instrumental. $\mathrm{O}$ grau em que qualquer sistema pode ser empregado de forma consistente é ainda mais restrito pelos limites físicos do instrumento e pela facilidade do violonista, ressaltando que, o que resulta na performance, provavelmente reflete as intenções do intérprete, tanto quanto as implicações das próprias digitações (YATES, 1998).
\end{abstract}

Alguns aspectos musicais devem ser considerados ao se efetuar uma digitação: recorrência motívica, melodia polifônica (incluindo os arpejos) e a disposição intervalar que divide uma ideia em melodia (graus conjuntos e/ou disjuntos). A observação destes aspectos possibilita ao violonista desempenhar uma divisão organizada de tarefas, na qual concebe a digitação da mão esquerda e a distribuição dos elementos musicais de maneira uniforme e coerente. A seguir apresentaremos os aspectos musicais citados acima:

Motivo - Segundo RETI (1951, p.11), “[é] qualquer elemento musical, seja ele uma frase ou fragmento melódico, ou mesmo uma característica rítmica ou dinâmica que é constantemente repetida e variada ao longo de um trabalho ou uma seção [...]". Para HORTA (1985, p.248), "Os temas musicais costumam dividir-se em motivos, mas a palavra [motivo] também é usada, às vezes, como sinônimo de tema”. Observamos a seguir, na Figura 7, um exemplo de motivo com sua respectiva digitação, nos c.17-19, do prelúdio da Suíte BWV 997:

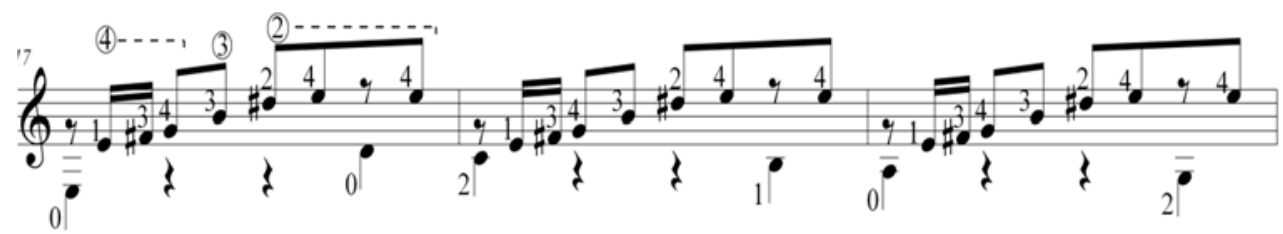

Figura 7: Motivo melódico. 
Melodia Polifônica - Conforme Fraga, citado por ALÍPIO (2010, p.39), “[...] é um recurso muito usado por compositores para "forjar" polifonia em instrumentos melódicos como a flauta ou o violino.” Desta maneira, "a concepção melódica que se encontra forjada em um aglomerado de saltos intervalares, pode conferir polifonia à obra" (ALÍPIO, 2010, p.39). Este recurso foi bastante explorado por Bach em suas composições, contudo sem fugir dos padrões melódicos e harmônicos do barroco.

\footnotetext{
Nas obras de Bach [...] a textura de 'melodias polifônicas' é bastante clara. Nessas peças, as melodias são facilmente identificáveis. Funcionalmente apresentam-se com as mesmas características dos contrapontos realizados em peças para conjuntos instrumentais polifônicos. Distribuídas em regiões específicas e delimitadas da tessitura, as diversas vozes dividem-se em sujeito, respostas, contrapontos, base harmônica, etc. De forma não restritiva, mas determinante, ao grave cabe a função de qualificar harmonicamente a peça e ao agudo e médio sua condução melódica linear. Assim, dentro dos padrões melódicos e harmônicos do Barroco, Bach garante a legitimidade de suas 'melodias polifônicas' de forma bastante particular sem, no entanto, fugir a uma linguagem coletiva e pertinente à sua época (Ferraz, citado por ALÍPIO, 2010, p.39-40).
}

Quando uma melodia encontra-se implícita, a digitação pode frisá-la permitindo a independência das diferentes vozes da obra. Nos c.29-31 do prelúdio da Suíte BWV 997 do exemplo a seguir, da Figura 8, mostra-se como se dá uma melodia polifônica por meio de uma digitação:

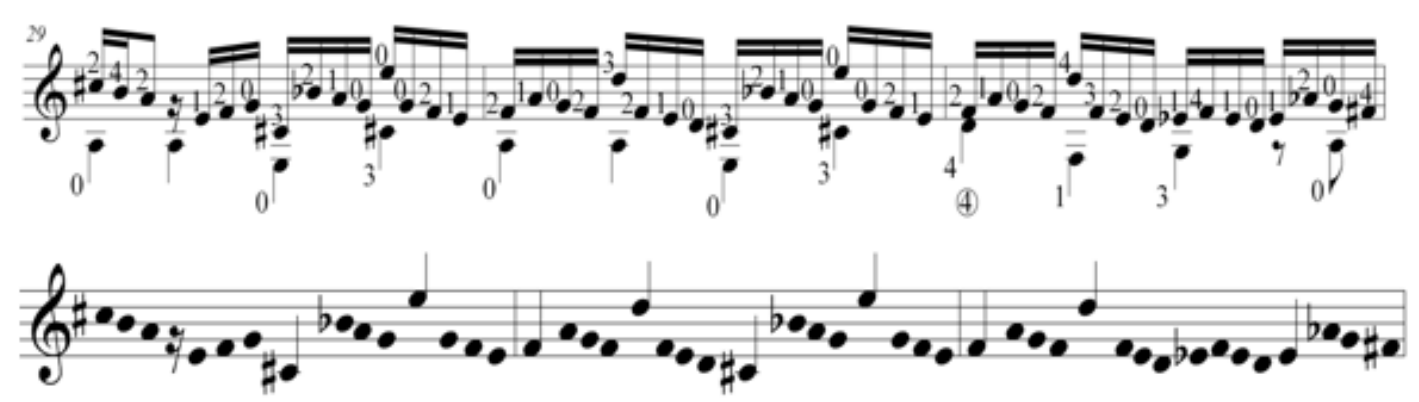

Figura 8: Melodia polifônica.

Contraponto - Segundo HORTA (1985, p.87), "técnica de combinar linhas musicais (o termo é do século XIV, derivado do latim punctus contra punctus, isto é, nota contra nota)". Trata-se de uma relação dupla em que elementos verticais e horizontais são simultaneamente 
contrastantes e independentes. No sentido horizontal, as duas linhas combinam e contrastam diferentes padrões rítmicos e melódicos, enquanto no plano vertical os intervalos resultantes são mutuamente complementares, sendo o termo quase sinônimo de polifonia. Observa-se nos c.33-34 do prelúdio da Suíte BWV 997, Figura 9, um modelo de contraponto entre a melodia principal e a linha do baixo com uma digitação que favorece a execução das duas vozes, uma vez que nenhuma delas está sendo interrompida ou cortada:

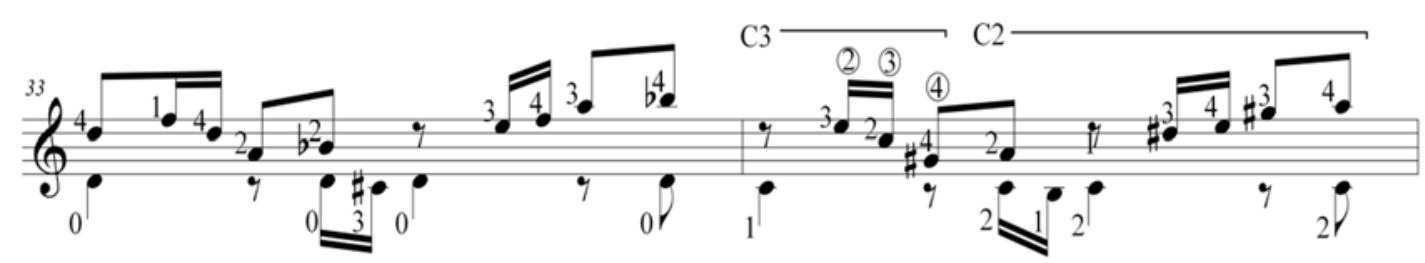

Figura 9: Exemplo de contraponto entre a melodia principal e o baixo.

Arpejos - De acordo com DONINGTON (1963, p.212), “o arpejo é um dispositivo para espalhar o som"; podendo este ajudar na polifonia da obra com os graus disjuntos ou conjuntos por meio de sua distribuição em cordas diferentes. Para ALÍPIO (2010, p.43), "Este tem ligação direta com a melodia polifônica; é uma forma de prolongar a duração das notas de uma melodia para obter um preenchimento harmônico". Um exemplo de arpejo em uma melodia foi o usado por Bach no prelúdio da Suíte BWV 997, c.11, da Figura 10:

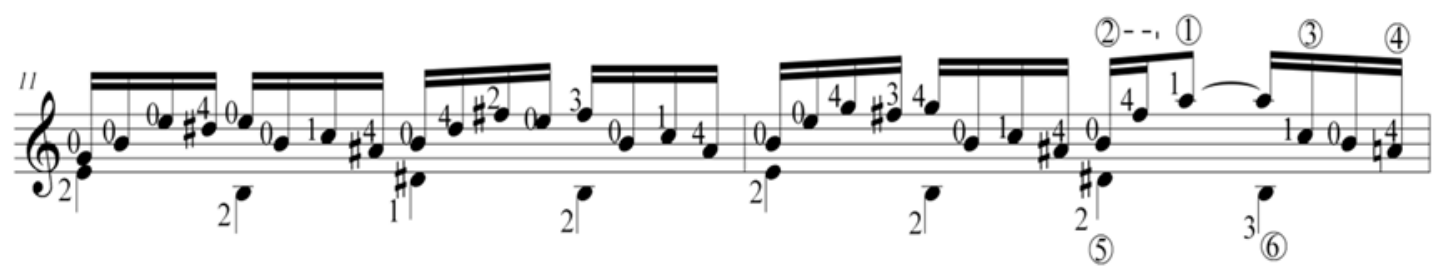

Figura 10: Arpejos melódicos.

Homogeneidade tímbrica - Segundo WOLFF (2001), para obter-se uma homogeneidade tímbrica, em alguns casos, é necessária a digitação em uma única corda. Entretanto, esse recurso geralmente resulta em diversos traslados de mão esquerda, devendo, portanto, ser reservado para passagens relativamente lentas nas quais as mudanças de posição não afetem a fluência da execução. Nos exemplos da Figura 11, a seguir, procurou-se manter coerência na digitação. Como já visto neste artigo, os exemplos nos dão mais de uma possibilidade, 
contudo, pretendeu-se usar uma digitação que correspondesse à afirmação de Wolff, buscando tocar o máximo de notas possíveis na mesma corda.
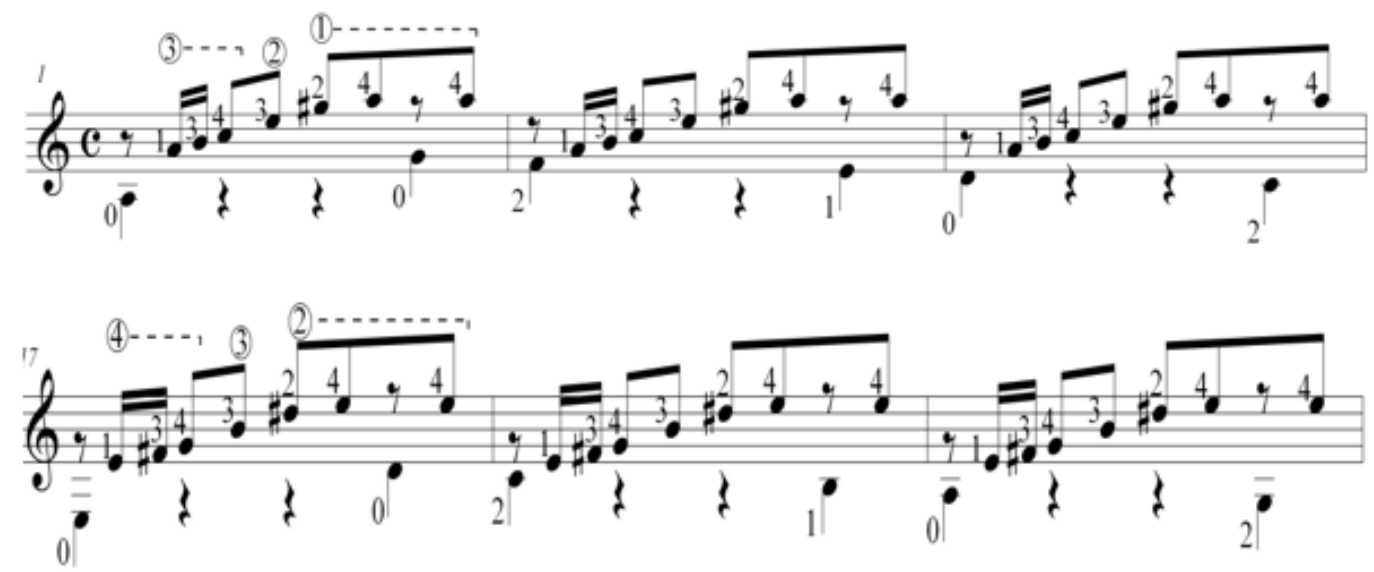

Figura 11: Homogeneidade tímbrica.

A digitação apresentada nas Figuras 7 a 11 dá a possibilidade para que o motivo, a melodia polifônica, o contraponto, o arpejo e a homogeneidade tímbrica, sejam contemplados, favorecendo a execução da obra.

\section{2 -Variações de digitação nas transcrições}

A averiguação em quatro transcrições, TURECK (1985), KOONCE (2002), DELCAMP (2009), e THORLAKSSON (2006), favoreceu a constatação de diferentes digitações existentes para uma mesma obra. E ainda nestes casos, os transcritores se eximiram de digitar alguns trechos musicais na partitura. O presente trabalho vem trazer uma nova digitação que contempla um número maior de notas musicais da obra. As diferentes digitações acima mencionadas ou mesmo quando estas não são indicadas podem ser observadas no prelúdio da Suíte BWV 997, a seguir, nas Figuras 12 a 21:

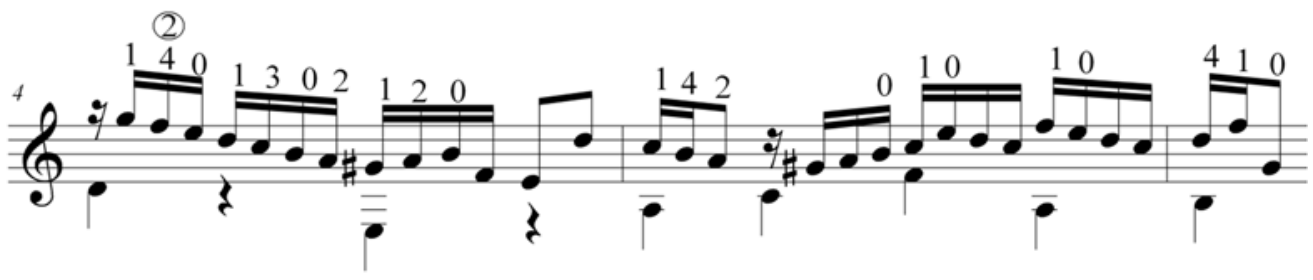

Figura 12: c.4-5 da transcrição de Tureck. 


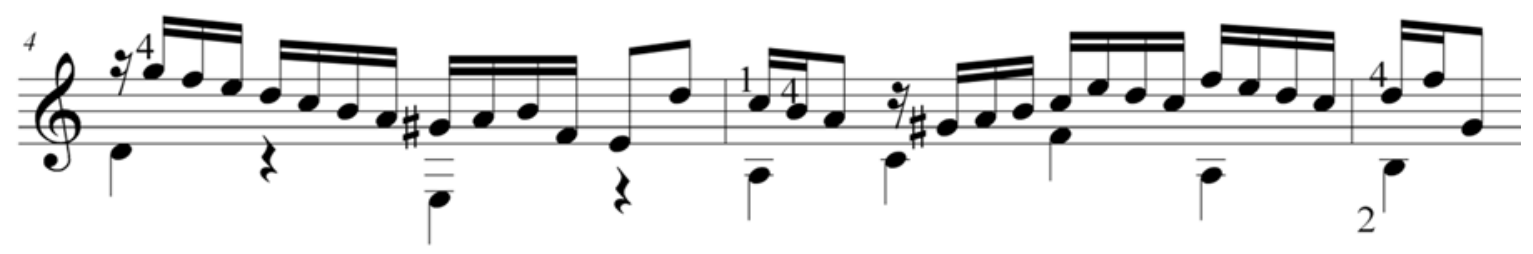

Figura 13: c.4-5 da transcrição de Koonce.

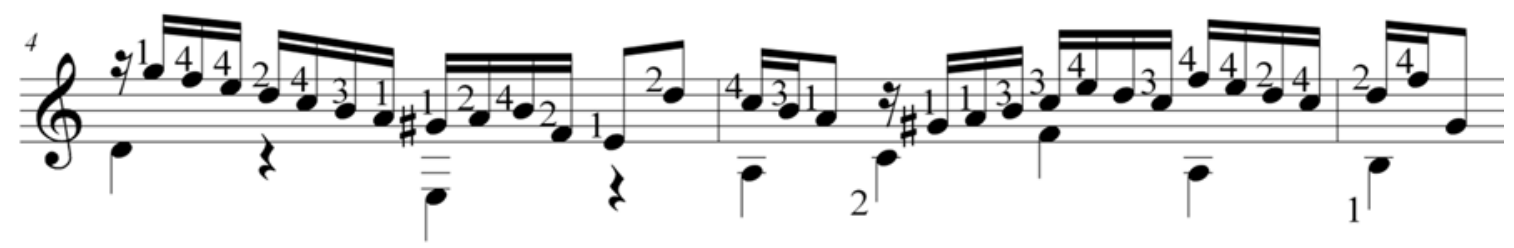

Figura 14: c.4-5 da transcrição de Delcamp.

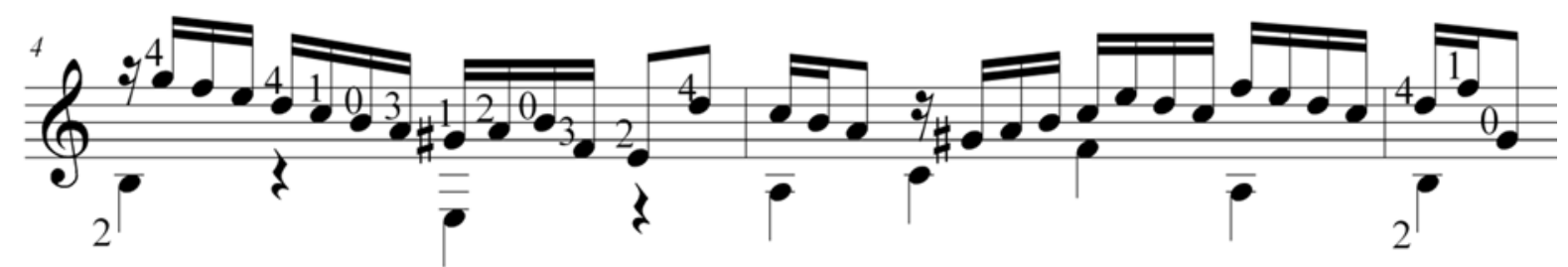

Figura 15: c.4-5 da transcrição de Thorlaksson.

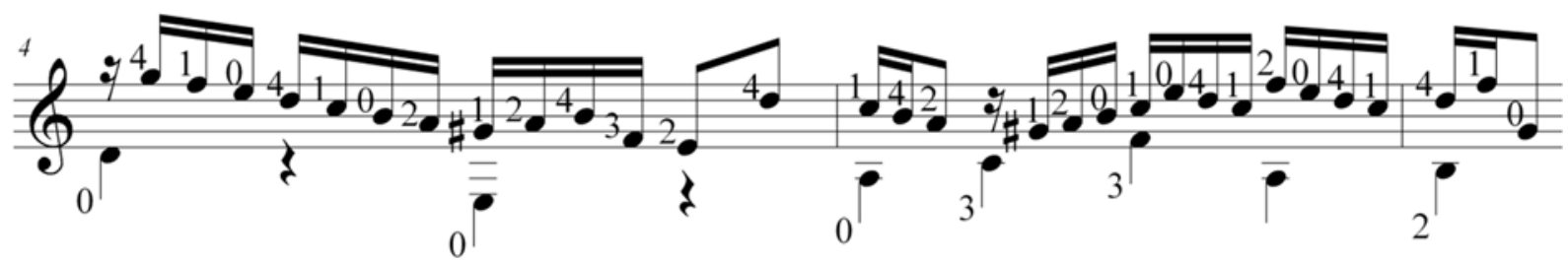

Figura 16: Proposta de Sousa para a Digitação.

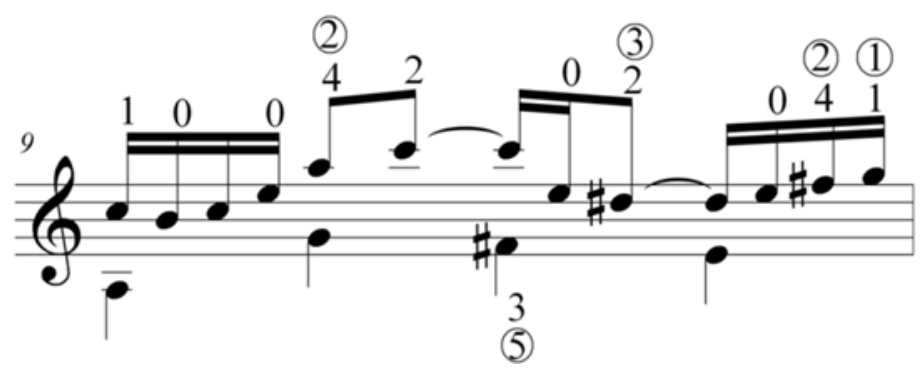

Figura 17: c.9 da transcrição de Tureck. 


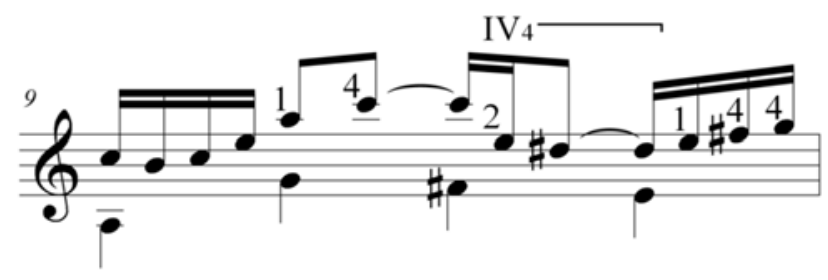

Figura 18: c.9 da transcrição de Koonce.

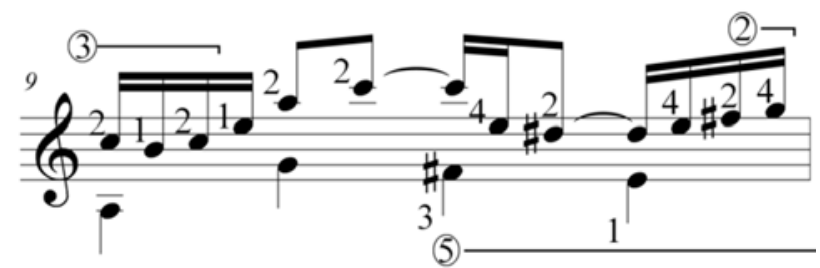

Figura 19: c.9 da transcrição de Delcamp.

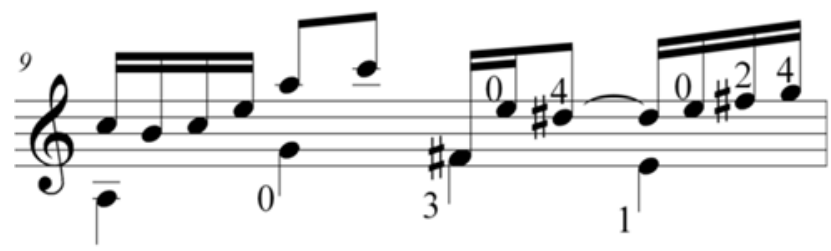

Figura 20: c.9 da transcrição de Thorlaksson.

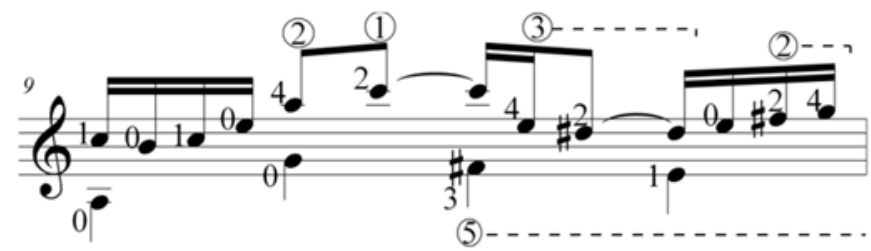

Figura 21: Proposta de Sousa para a Digitação.

Um ponto a ser observado é o fato de nos fac-símiles disponíveis não haver uma digitação própria do instrumento pela qual a obra fora composta originalmente, como apresentado, a seguir, nas Figuras 22 e 23: 


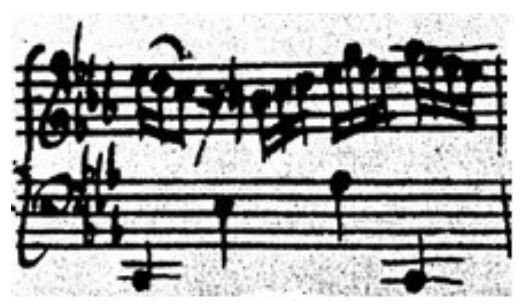

Figura 22: c.5 do fac-símile (KOONCE, 2002, p.124).

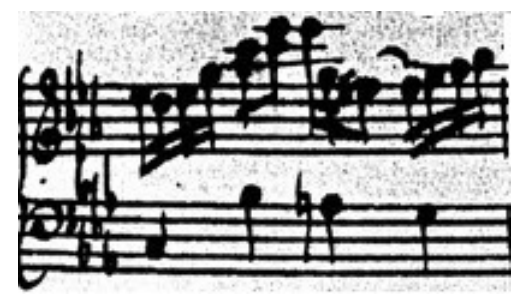

Figura 23: c.9 do fac-símile (KOONCE, 2002, p.124).

\section{3 - Transcrição para violão}

Esta parte do trabalho trata das modificações feitas pelos transcritores com relação à obra original. Uma vez que se percebeu divergência entre as transcrições, este assunto tornou-se importante para se chegar a uma nova digitação.

A transcrição, prática muito comum nos tempos de Bach, favorecia a execução de obras não originais para os instrumentos. Hoje uma considerável quantidade dessas obras é transcrita para piano ou violão. Para tanto, ALÍPIO (2010, p.23) afirma que "Desde a época de Bach, várias transcrições distintas de sua obra foram realizadas para outros instrumentos, particularmente para o piano e para o violão". Para este último, a grande quantidade de transcrições existentes é atribuída à sua "completude polifônica e textual” (YATES, 1998).

Originalmente a Suite BWV 997 é composta para o alaúde na tonalidade de Dó menor, mas para a realização da transcrição, considerando que o alaúde possuía afinação diferenciada do violão, como mostra a Figura 24, foi necessária a mudança da tonalidade para Lá menor: 


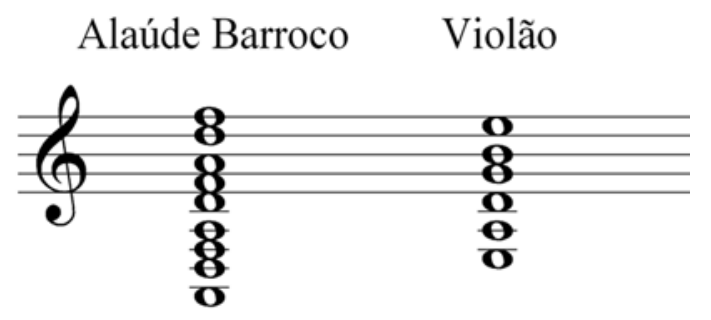

Figura 24: Comparação entre as afinações do Alaúde Barroco e do Violão.

A mudança de tom realizada pelos transcritores pode ser atribuída aos mesmos motivos que alguns arranjadores se apropriam da prática da scordatura ${ }^{5}$.

\begin{abstract}
O uso de scordatura é uma prática comum entre os instrumentos de cordas através da história [...] tal mudança pode ser com o intuito de ampliar a tessitura ${ }^{6}$ do instrumento, ou explorar novas cores, timbres, sonoridades e possibilidades harmônicas alternativas (BORGES, 2007, p.19-20).
\end{abstract}

Na música renascentista para alaúde (ou mesmo o barroco) é necessário realizar algum tipo de adaptação da música em relação ao instrumento, principalmente nos baixos, pois a tessitura do alaúde é maior para o grave do que o violão (WOLFF, 1998). A adaptação aqui realizada pelos transcritores se deu na mudança de tonalidade, procurando atender da melhor maneira possível às exigências idiomáticas e estilísticas da obra.

Conforme referido anteriormente, neste trabalho foram selecionadas quatro transcrições do Prelúdio da Suíte BWV 997. Em seguida, realizou-se um cotejamento nas mesmas, o que favoreceu a percepção das várias possibilidades de digitações, além de notações distintas quanto à representação de alguns valores rítmicos e de determinadas alturas. No entanto, o presente trabalho não objetivou verificar a diversificação da escrita, de ornamentação e de articulação (apesar desses serem importantes para a interpretação musical), e sim, os elementos que podem influenciar no discurso musical, como por exemplo, notas oitavadas, notas diferenciadas e consequentemente a digitação, que é o foco principal deste trabalho.

\footnotetext{
${ }^{5}$ Termo utilizado para designar uma afinação que se utiliza de um conjunto de alturas diferentes daquelas consideradas convencionais de determinado instrumento de corda (CAMPBELL, 2004, p.277).

${ }^{6}$ Altura média das notas em uma composição. Se houver preponderância de notas agudas, diz-se que a tessitura é alta; o inverso também se aplica. O termo é mais frequentemente usado em relação à música vocal do que a instrumental (HORTA, 1985, p.382).
} 
Diferenças observadas nas transcrições podem ser percebidas nas Figuras 25 a 26 e 28 a 30 . Já as Figuras 27 e 31 mostram como a música está escrita no fac-símile. As figuras foram editadas para melhor visualização:

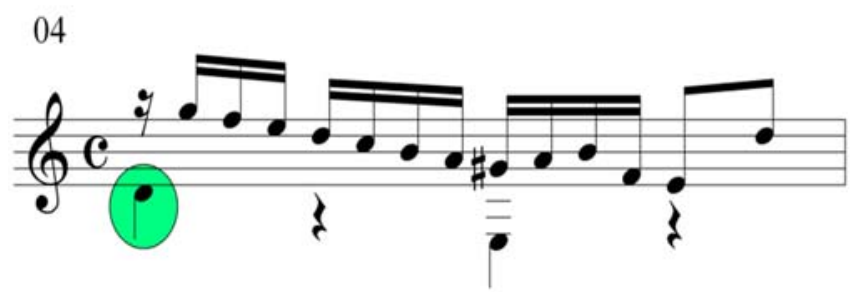

Figura 25: c. 4 das transcrições de Koonce, Tureck e Delcamp.

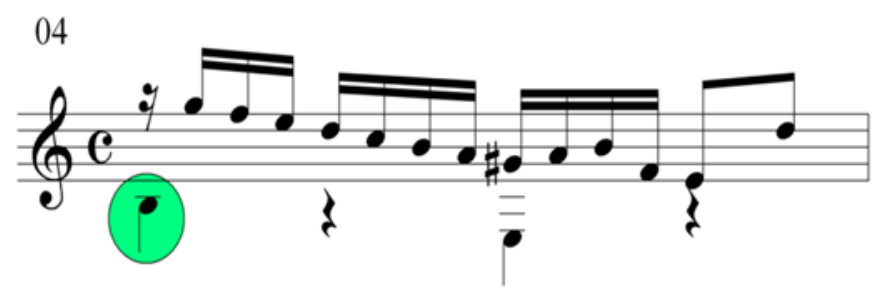

Figura 26: c.4 da transcrição de Thorlaksson.

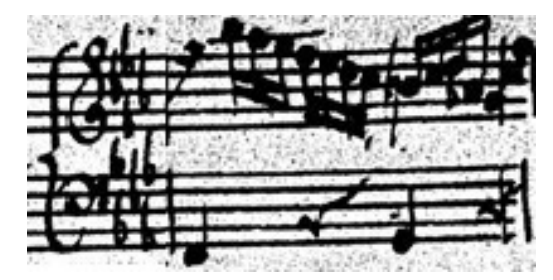

Figura 27: c.4 do fac-símile (KOONCE, 2002, p.124).

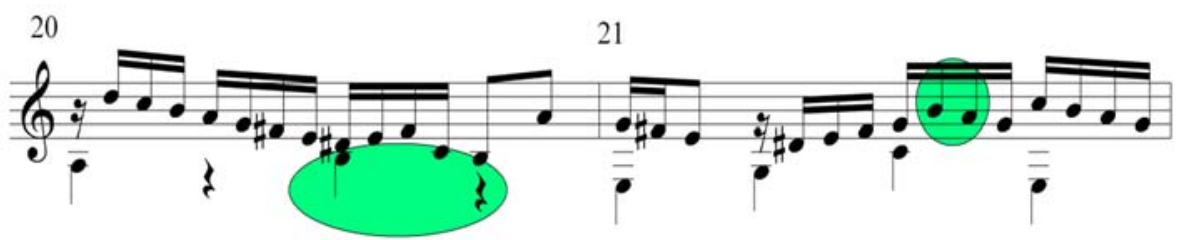

Figura 28: c.20-21 das transcrições de Koonce e Tureck. 


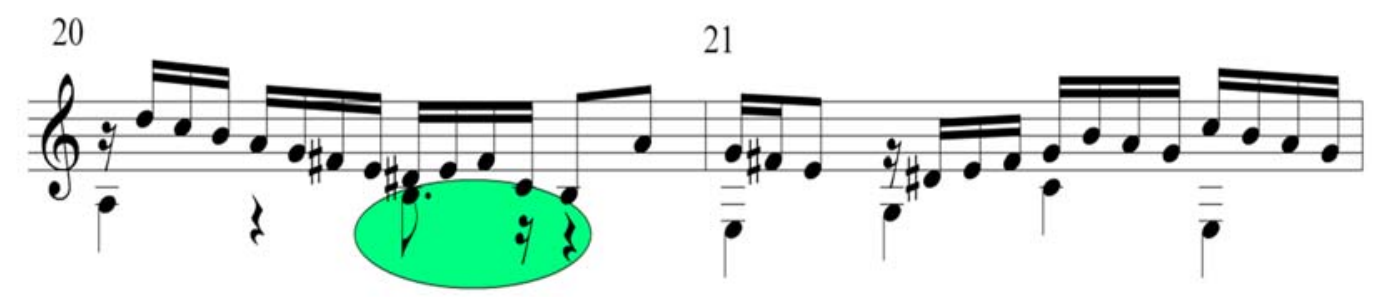

Figura 29: c.20-21 da transcrição de Delcamp.

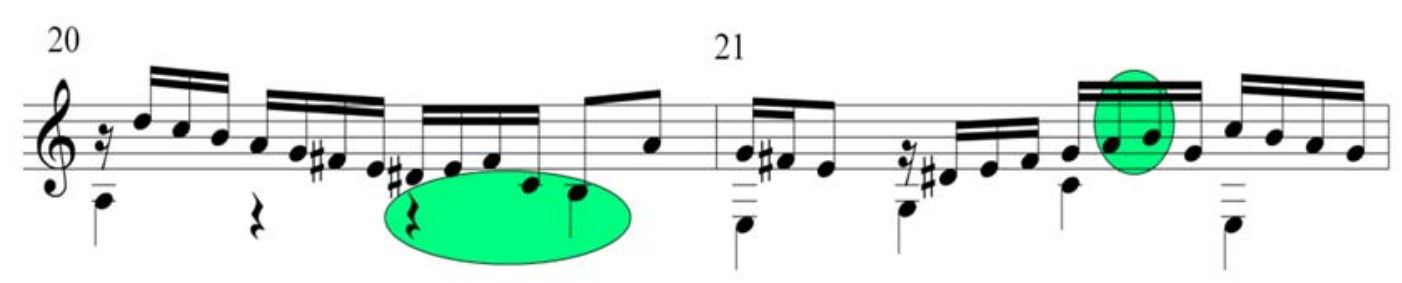

Figura 30: c.20-21 da transcrição de Thorlaksson.

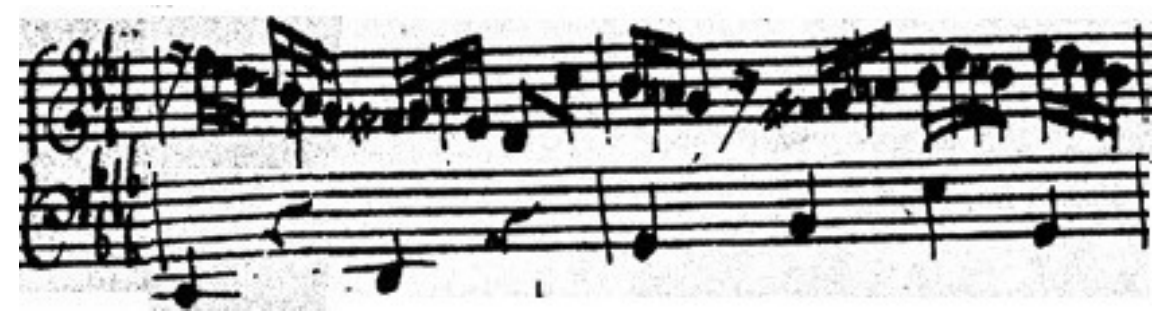

Figura 31: c.20-21 do fac-símile (KOONCE, 2002, p.124).

\section{3 - Considerações Finais}

Ao realizar o cotejamento, constatou-se a presença de notas distintas quanto à representação de seus valores rítmicos e de suas alturas. Esta prática foi decisiva para que uma nova digitação fosse realizada, uma vez que o valor rítmico e a altura da nota tinham que ser definidos. Tal procedimento (cotejamento) também favoreceu para que as diferentes digitações entre as transcrições fossem verificadas, levando o autor a sugerir uma própria.

O trabalho dissertou sobre os aspectos da digitação e seu referencial teórico, os quais foram abordados numa ordem pré-determinada. O primeiro aspecto foi "motivos", pela qual foi atribuída uma digitação que estabelecesse padrões e conexões entre os mesmos. Em seguida, 
"melodia polifônica", que estabeleceu uma digitação que tornasse visível a polifonia existente na melodia da obra. Depois, "contraponto", onde a digitação favoreceu uma melhor fluência das vozes envolvidas e, por último, "arpejos", que procurou digitar os trechos em que estes se encontravam, de maneira que houvesse uma sensação harmônica através das cordas adjacentes sustentadas e "homogeneidade tímbrica". Isso permitiu indicar uma digitação que favorecesse a execução da melodia ou linha do baixo em uma única corda, sempre que possível, para não haver diferenças de timbre entre suas notas.

A proposição de uma digitação grafada em uma obra pode incorrer em algumas limitações, decorrentes das diferentes habilidades do violonista, dimensões dos instrumentos, tamanhos de mão, entre outras. Entretanto, o objetivo deste trabalho não foi determinar uma única digitação, mas sim de oferecer uma possibilidade a outros músicos intérpretes, a qual não é definitiva e poderá ser modificada ou aperfeiçoada pelos leitores por seus próprios pontos de vista, ou ainda mesmo, pelo autor, uma vez que a interpretação musical possibilita diferentes leituras de uma mesma obra e, consequentemente, diferentes digitações.

\section{Referências}

1. ALÍPIO, A. (2010). O Processo de digitação para violão da ciaccona BWV 1004 de Johann Sebastian Bach. 2010. Dissertação de mestrado - Universidade Federal do Rio Grande do Sul, Porto Alegre.

2. ARAÚJO, M. V. (2011). Estratégias de estudo utilizadas por dois guitarristas na preparação para execução musical da Elegy de Alan Rawsthorne. Revista Guitarra Clássica, n.5.

3. BORGES, R. G. (2007). O uso de scordatura para a execução no violão de obras compostas para alaúde barroco: transcrição e exemplos extraídos da obra de Silvius Leopold Weiss. Dissertação de mestrado - Universidade Federal do Rio Grande do Sul, Porto Alegre.

4. CAMPBELL, M. (2004). Musical Instruments: History, Technology, and Performance of Instruments of Western Music. New York: Oxford University Press.

5. DART, T. (1991). Interpretação da Música. Martins Fontes: Brasil.

6. DONINGTON, R. (1963). The Interpretation of Early Music. London: Faber and Faber. 
7. FERNÁNDEZ, E. (2000). Técnica, mecanismo y aprendizaje: Uma investigación sobre cómo llegar a ser guitarrista. Ediciones Art-Montevideo - Uruguay.

8. FERREIRA, A. B. de H. (1988). Transcrição. In: Novo Dicionário Básico da Língua Portuguesa. Rio de Janeiro: Folha de São Paulo.

9. HORTA, L. P. (1985). Dicionário de Música Zahar. Rio de Janeiro: Zahar.

10. MAIA, M. da S. (2007). Técnica Híbrida aplicada ao violão. Dissertação de mestrado - Universidade Estadual de Campinas, Campinas.

11. PINTO, H. (1978). Iniciação ao violão: princípios básicos e elementares para principiante. São Paulo: Ricordi.

12. POSTLEWATE, C. (2001). Right-Hand Studies for Five Fingers. U.S.A.: Mel Bay.

13. RETI, R. (1951). The thematic process in music. Londres: Faber.

14. SILVEIRA FILHO, F. G. D. da. (2004). Uma análise da digitação grafada nas Five Bagatelles de William Walton. Dissertação de mestrado - Universidade Federal do Rio Grande do Sul, Porto Alegre.

15. SADIE, S. (1994). Dicionário Grove de Música. Edição concisa - Rio de Janeiro: Ed. Zahar.

16. WOLFF, D. (1998). Transcribing for guitar: a comprehensive method. Tese (Doutorado) - Manhattan School Of Music, New York.

17. São Paulo, n.46. . (2001). Como digitar uma Obra para Violão. Revista Violão Intercâmbio,

18. YATES, S. (1998). Bach's unaccompanied string music: A new (old) approach to stylistic and Idiomatic transcription for the guitar. Disponível em:

$<$ www.stanleyyates.com/articles/bacharr/intro.html>. Acesso em: 15 de maio de 2008.

\section{Referências de partituras}

1. DELCAMP, J. F. Partita BWV 997 Prélude, Fugue, Sarabande, Gigue et Double. 2009. Disponível em:

$<$ http://www.delcamp.net/pdf/johann sebastian bach bwv 997 partita prelude fugue sarabande gigue et double.pdf $>$. Acesso em: em 16 de março de 2010.

2. KOONCE, F. Johann Sebastian Bach The Solo Lut Works. Neila A. Kjos Music Copany: San Diego - California, 2 edição: 2002. 
3. THORLAKSSON, E. Joh. Seb. Bach Lute Suite Nr. 2 Guitar solo. 2006. Disponível em: $<$ http://www.classicalguitarschool.net/music/1062.pdf> . Acesso em: em 16 de março de 2010 .

4. TURECK, R. Suite in C minor, BWV 997. New York: Schirmer Books, 1985.

Notas sobre os autores

Natanael Martins de Sousa é licenciado em música pela Universidade Estadual do Ceará UECE. Especialista em Arte Educação para o Ensino de Música pela Faculdade de Tecnologia Darcy Ribeiro - FTDR. Foi membro eleito do Conselho de Centro (CONCEN) do Centro de Humanidades da UECE nos anos de 2009 e 2010. Atuou como professor temporário da Secretaria da Educação do Estado do Ceará no ano letivo de 2012. Atualmente é professor de artes da Secretaria Municipal de Educação de Fortaleza-CE e tem dedicado maior parte de seu tempo ao estudo performático do violão e a pesquisas em educação musical.

Marcos da Silva Maia é Mestre em Música pela UNICAMP e graduado em Licenciatura em Música pela UECE, onde desde 1988, integra o quadro de docentes efetivos, como professor de Prática Instrumental - Violão e Guitarra. Apresentou-se como solista convidado em várias orquestras. Em 1998, lançou o primeiro CD - Ciclos - de composições autorais para violão. Foi vencedor do prêmio de Melhor Trilha Sonora Original no $25^{\circ}$ Festival Guarnicê de Cinema, São Luís (MA) em junho de 2002. Foi um dos selecionados pelo Projeto Rumos Musicais - Tendências e Vertentes - do Itaú Cultural (2000). Ministrou oficinas de violão e foi coordenador artístico e pedagógico no Festival Música na Ibiapaba, na cidade de Viçosa (CE) e nas Residências Artísticas do Festival Jazz e Blues em Guaramiranga (CE). 


\section{Anexo 1}

\section{PRELÚDIO DA SUITE BWV 997 ORIGINAL PARA ALAÚDE E TRANSCRITA PARA VIOLÃ̃O}

Transcrição: Jean-François Delcamp

Johann Sebastian Bach (1685-1750)

Digitação: Natanael Martins de Sousa
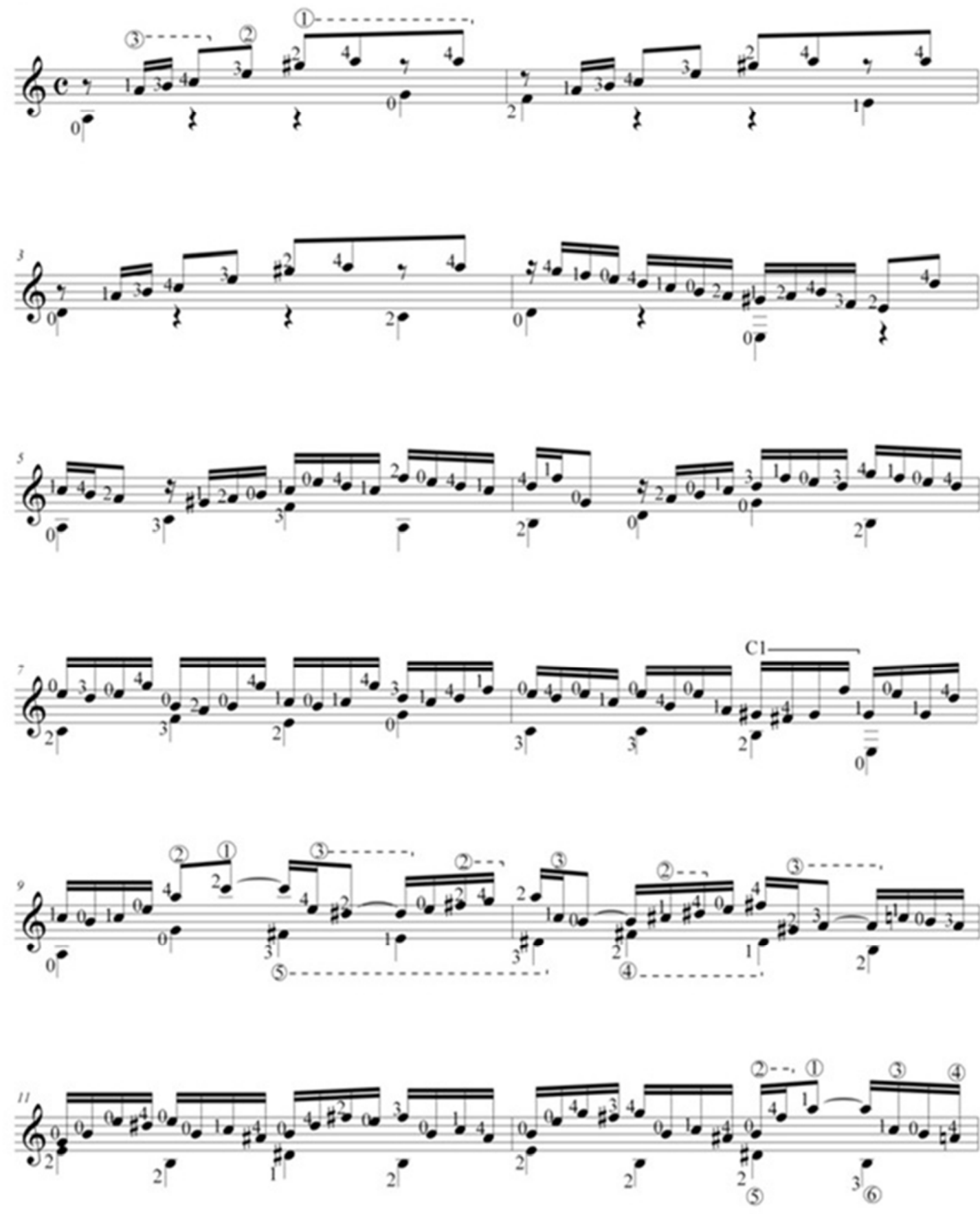

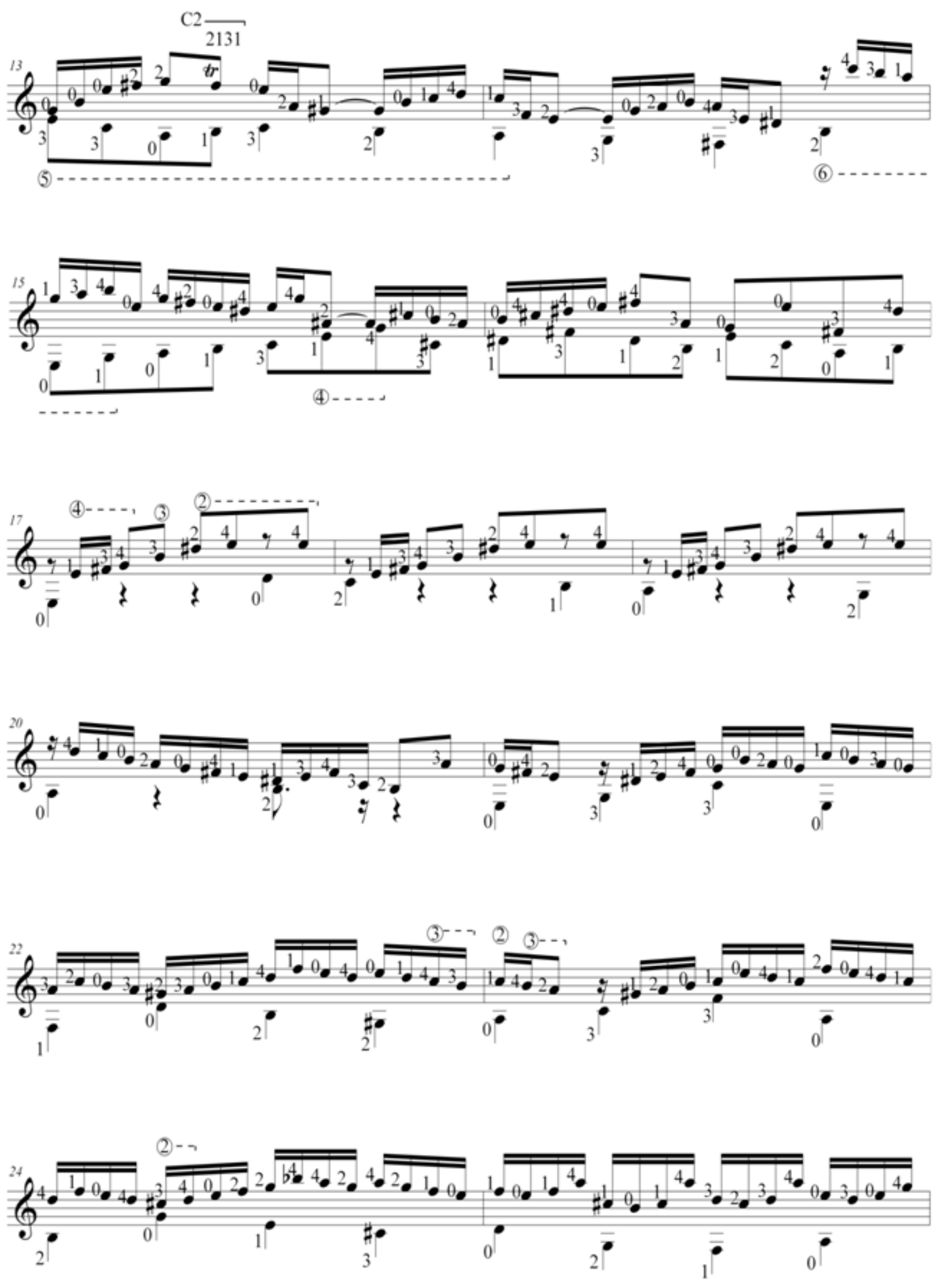

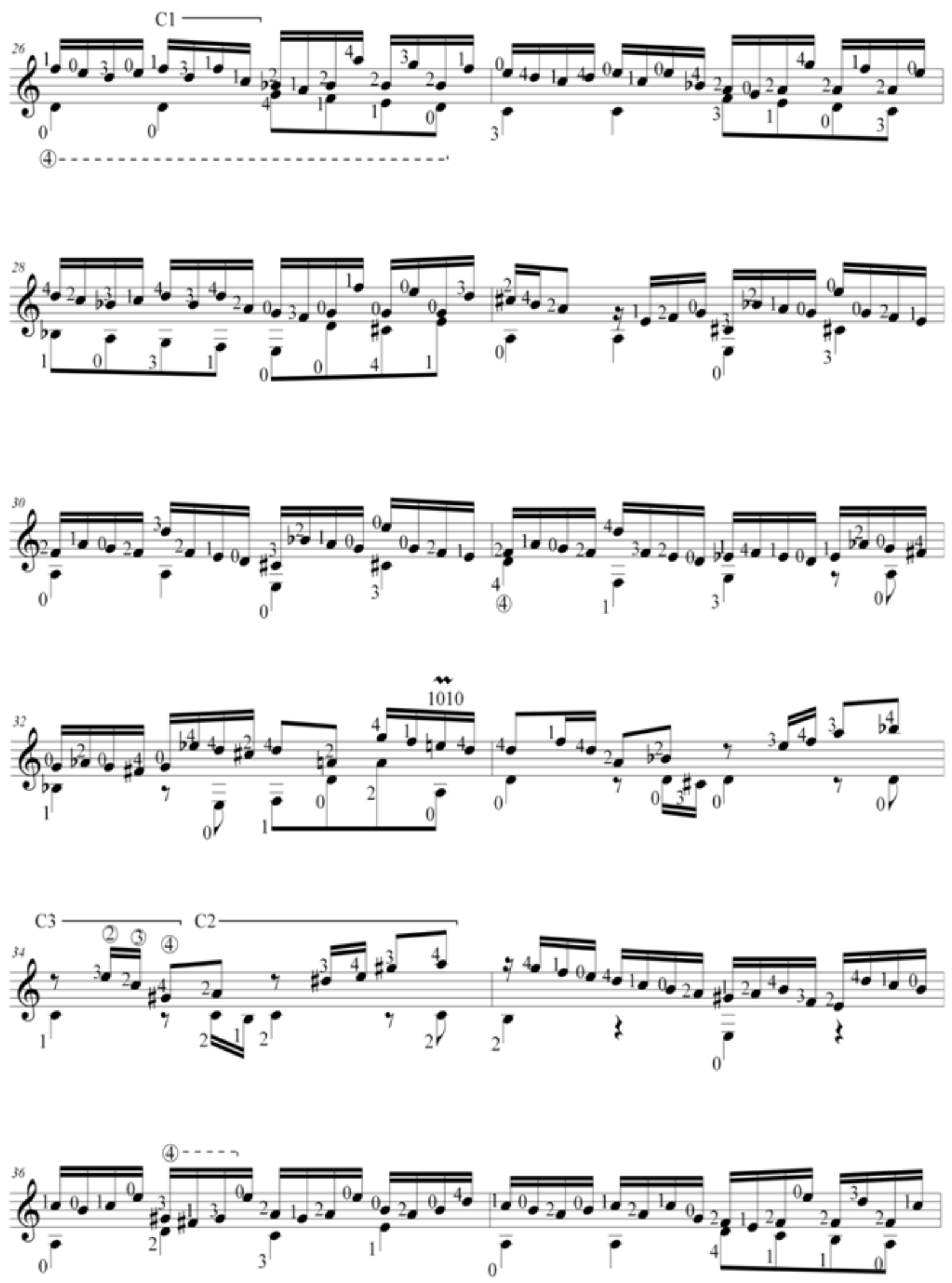

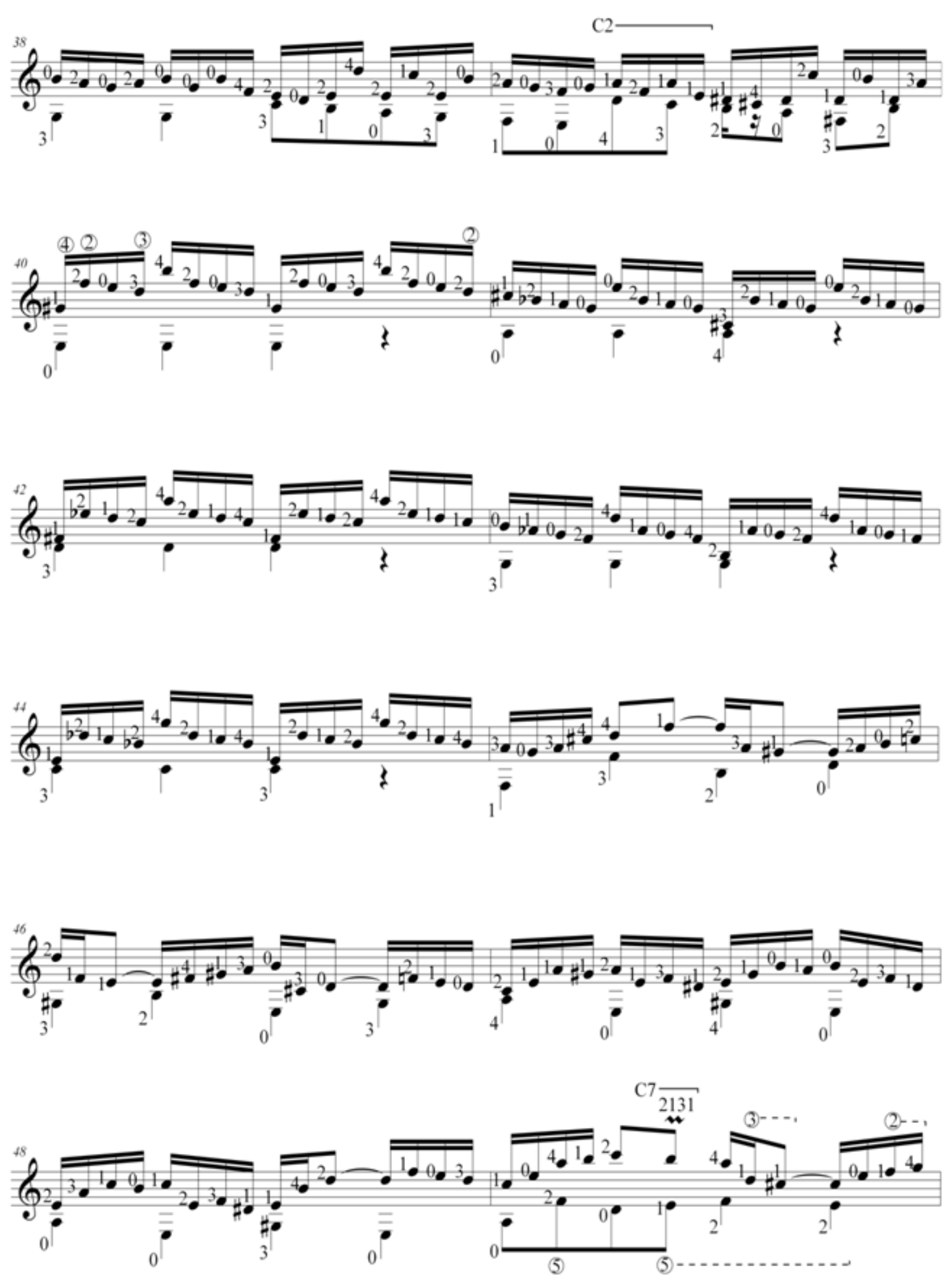

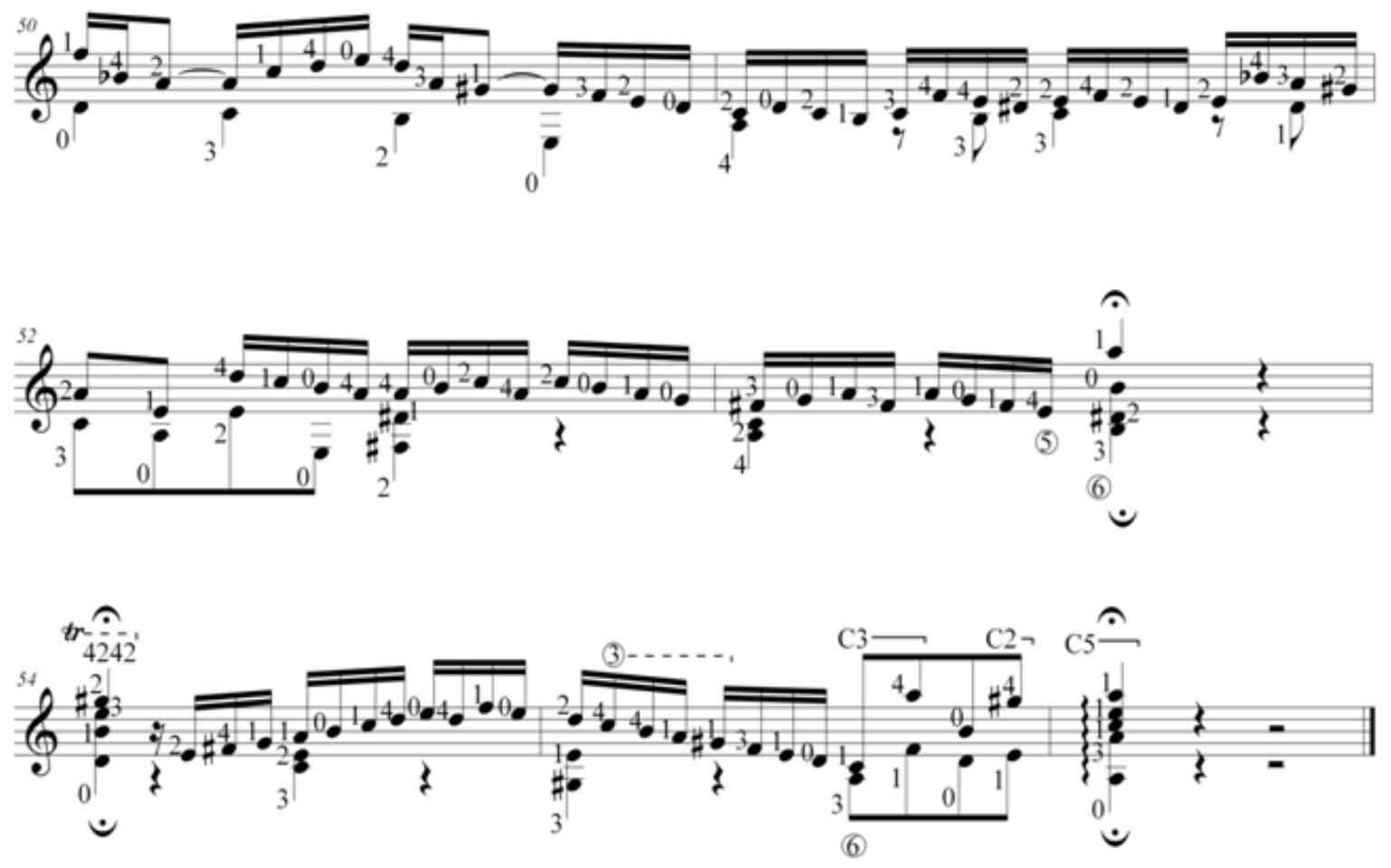


\section{Anexo 2}

Suíte, BWV 997, cópia do manuscrito de J. F. Agricola (Fonte A), cortesia da Biblioteca Estadual de Berlim - Kulturbesitz Editores (Koonce, 2002, p.124).
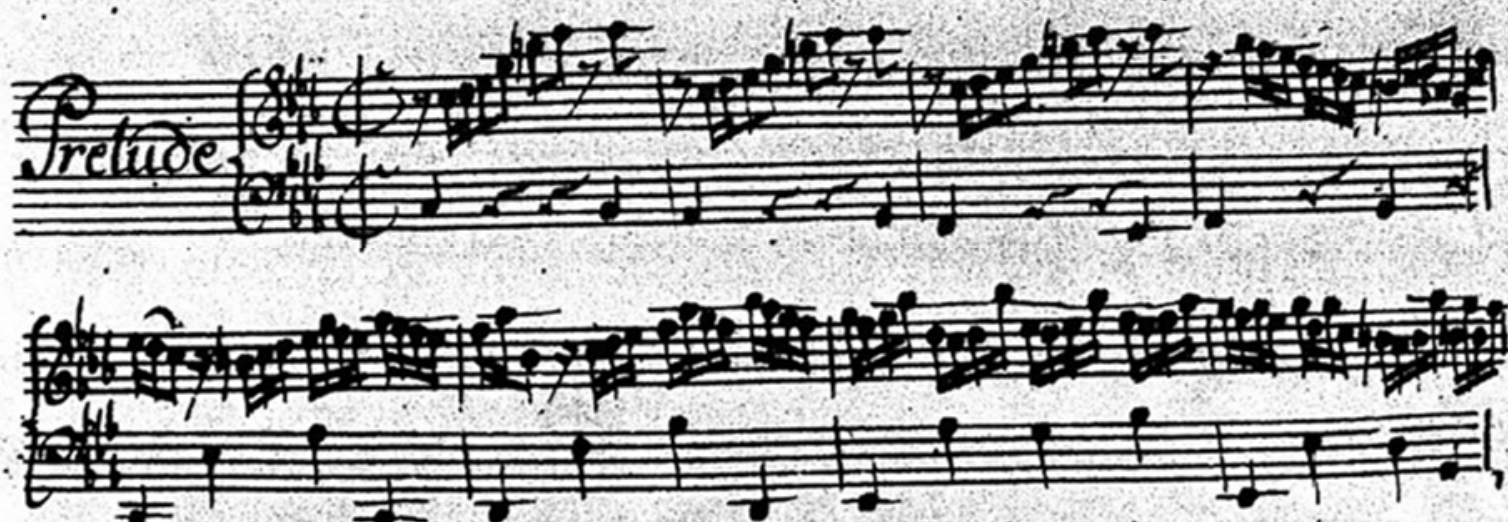
(n)

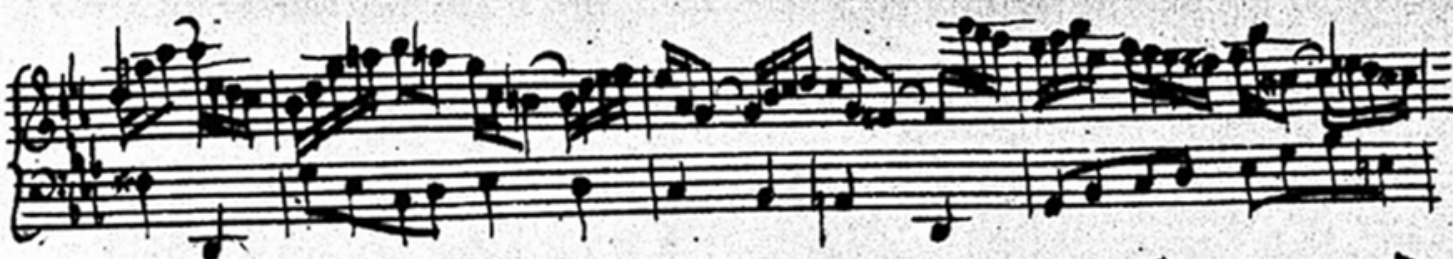
(0.1)

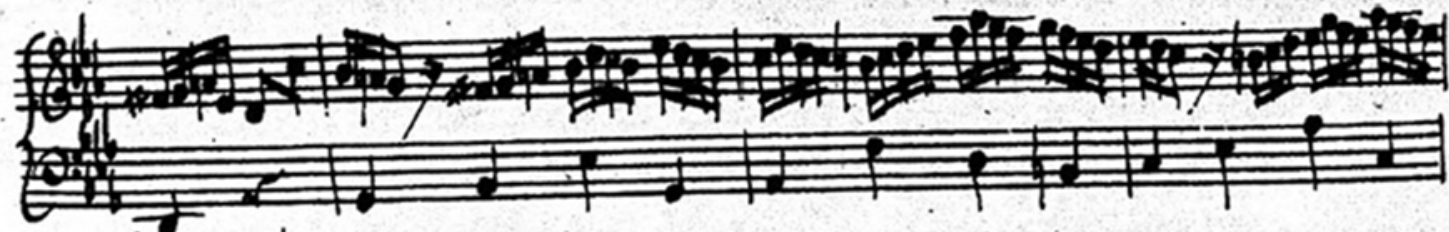
fod,

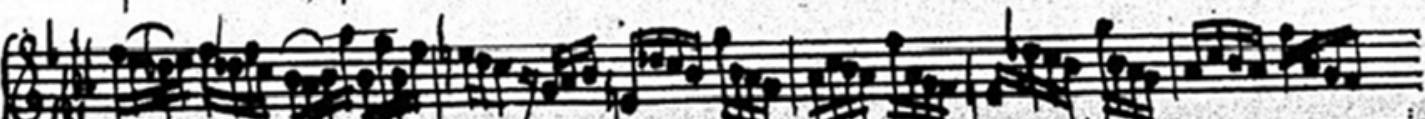
En

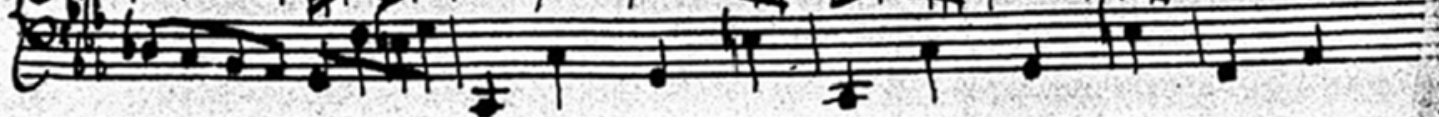

